\title{
Stratified Community Responses to Methane and Sulfate Supplies in Mud Volcano Deposits: Insights from an In Vitro Experiment
}

\author{
Yu Zhang ${ }^{1,2}$, Lois Maignien ${ }^{2}$, Alina Stadnitskaia ${ }^{3}$, Pascal Boeckx ${ }^{4}$, Xiang Xiao ${ }^{1 *}$, Nico Boon ${ }^{2 *}$ \\ 1 State Key Laboratory of Microbial Metabolism, State Key Laboratory of Ocean Engineering, Shanghai Jiao Tong University, Shanghai, People's Republic of China, \\ 2 Laboratory of Microbial Ecology and Technology, Ghent University, Gent, Belgium, 3 Department of Marine Geology and Chemical Oceanography, Royal Netherlands \\ Institute for Sea Research, Texel, the Netherlands, $\mathbf{4}$ Laboratory of Applied Physical Chemistry, Ghent University, Gent, Belgium
}

\begin{abstract}
Numerous studies on marine prokaryotic communities have postulated that a process of anaerobic oxidation of methane (AOM) coupled with sulfate reduction (SR) is the main methane sink in the world's oceans. AOM has also been reported in the deep biosphere. But the responses of the primary microbial players in eliciting changes in geochemical environments, specifically in methane and sulfate supplies, have yet to be fully elucidated. Marine mud volcanoes (MVs) expel a complex fluid mixture of which methane is the primary component, forming an environment in which AOM is a common phenomenon. In this context, we attempted to identify how the prokaryotic community would respond to changes in methane and sulfate intensities, which often occur in MV environments in the form of eruptions, diffusions or seepage. We applied an integrated approach, including (i) biochemical surveys of pore water originated from MV, (ii) in vitro incubation of mud breccia, and (iii) prokaryotic community structure analysis. Two distinct AOM regions were clearly detected. One is related to the sulfate methane transition zone (SMTZ) at depth of 30-55 cm below the sea floor (bsf); the second is at 165$205 \mathrm{~cm}$ bsf with ten times higher rates of AOM and SR. This finding contrasts with the sulfide concentrations in pore waters and supports the suggestion that potential AOM activity below the SMTZ might be an important methane sink that is largely ignored or underestimated in oceanic methane budget calculations. Moreover, the incubation conditions below the SMTZ favor the growth of methanotrophic archaeal group ANME-2 compared to ANME-1, and promote the rapid growth and high diversity of bacterial communities. These incubation conditions also promote the increase of richness in bacterial communities. Our results provide direct evidence of the mechanisms by which deep AOM processes can affect carbon cycling in the deep biosphere and global methane biochemistry.
\end{abstract}

Citation: Zhang Y, Maignien L, Stadnitskaia A, Boeckx P, Xiao X, et al. (2014) Stratified Community Responses to Methane and Sulfate Supplies in Mud Volcano Deposits: Insights from an In Vitro Experiment. PLoS ONE 9(11): e113004. doi:10.1371/journal.pone.0113004

Editor: Daniele Daffonchio, University of Milan, Italy

Received July 9, 2014; Accepted October 17, 2014; Published November 13, 2014

Copyright: (C) 2014 Zhang et al. This is an open-access article distributed under the terms of the Creative Commons Attribution License, which permits unrestricted use, distribution, and reproduction in any medium, provided the original author and source are credited.

Data Availability: The authors confirm that all data underlying the findings are fully available without restriction. All relevant data are within the paper and its Supporting Information files.

Funding: This work was supported by Natural Science Foundation of China (grant numbers 41102211 and 91228201), National High-Tech Program of China (grant number 2012AA092103), Bijzonder Onderzoeks Fonds of Ghent University (grant number BOF08/DOC/016, BOF09/GOA/005), European Science Foundation MicroSYSTEMS supported by Fonds voor Wetenschappelijk Onderzoek (grant number 506G.0656.05). The funders had no role in study design, data collection and analysis, decision to publish, or preparation of the manuscript.

Competing Interests: The authors have declared that no competing interests exist.

*Email: xoxiang@sjtu.edu.cn (XX); Nico.Boon@ugent.be (NB)

\section{Introduction}

The existence of microbial life in the deep subsurface has been known since ZoBell's studies in the 1930s [1] and was first proven in sediment cores during drilling in the 1980s [2]. However, whether the deep biosphere is the largest prokaryotic habitat on Earth is an enigma because the estimations of cell numbers and biomass differ dramatically among sampling sites and counting techniques [3-5]. The importance of these deeply buried communities for driving carbon and nutrient cycling and for catalyzing a multitude of reactions among rocks, sediment and fluids is widely accepted [6]. Available reports demonstrate that the highest quantities of active prokaryotes are associated with diverse biogeochemical interfaces, e.g., highly organic rich sediments such as the Mediterranean sapropels [7]; the sulfate methane transition zone (SMTZ), where anaerobic methanotro- phy is the driving force behind local microbial activities [4]; the deep hypersaline anoxic lakes, where the ecosystems are largely driven by sulfur cycling and methanogenesis [8]; an increase in microbial biomass was also observed in sediments with gas hydrates [9].

Recent developments in research on the marine methane cycle have shown that the anaerobic oxidation of methane (AOM) is the key microbial action responsible for methane turnover in the ocean and is the first step in making energy available to the local ecosystem [10]. The AOM process has been proposed to involve reverse methanogenesis $[11,12]$, which is coupled with sulfate reduction via anaerobic methanotrophic archaea (ANME) and diverse sulfate-reducing bacteria (SRB) [13,14]. Because ANME and SRB annually consume approximately $85 \%$ of oceanic methane production, the assessment of in situ AOM rates plays a vital role in global methane budget modeling [10]. Currently, 
estimations of in situ AOM rates are primarily based on the methane/sulfate turnover rates using radioactive tracers. Longterm incubation under simulated conditions has not been frequently reported and has only been performed at shallow sediment depths near the SMTZ [10].

Marine mud volcanoes (MVs) are among the most spectacular seepage-related geomorphological structures and produce a strong outburst of methane-saturated geofluids from the deep subsurface. The development of a MV is related to strong lateral or vertical compressions of the Earth's crust that provoke deep-lying sediments to move upward [15]. Such emitted sedimentary material is called "mud breccia" and represents exclusively MVrelated deposits [16]. The main gaseous component in the seeping fluids is methane, a strong greenhouse gas. In addition to methane, mixtures of wet gas, hydrogen sulfide, carbon dioxide, and petroleum products are often present. Such chemically complex allochthonous sedimentary and fluid mixtures incite the development of particular environments at and below the sea floor and fuel microbial processes that shape the community structure of the chemosynthetic seepage.

MVs are known to exhibit environmental heterogeneity, which is directly related to the mode of MV eruptions and to the chemistry of the expelled products. Hydrocarbon-rich fluids expelled to the surface bring up methane, which is utilized as a carbon and energy source. Because AOM is the initial step in biological energy conversion within the local ecosystem, the bioavailability of methane directly determines energy supply and the biomass in the sediment along the fluid migration pathway. Additionally, microbial AOM activity controls the storage of methane in the ocean. However, the distribution of active methane-consuming microbes, especially those that perform anaerobic methanotrophy along the sedimentary section of a MV, has yet to be sufficiently investigated. Furthermore, the organization of prokaryotic communities and their structure at varying sedimentary depths and in environments with variable methane concentrations has not been reported thus far. To test the potential for in situ AOM activity, we report the results of an in vitro incubation experiment under methane- and sulfate-rich conditions that was performed on freshly recovered mud breccia from the Ginsburg MV in the Gulf of Cadiz (Fig. 1). The availability of freshly erupted MV deposits allowed us to examine potential AOM activity at and below the SMTZ. We applied a vertical profile sampling strategy to reveal changes in AOM community structure and its spatial distribution at varying depths and to identify possible ecological factors that influence the community's metabolic behavior and dynamics.

\section{Materials and Methods}

\section{Sampling site location and lithology}

Sampling location is Ginsburg MV $\left(35^{\circ} 22.431^{\prime} \mathrm{N}\right.$; $07^{\circ} 05.291^{\prime} \mathrm{W}$ ) in the Gulf of Cadiz. The field studies did not involve endangered or protected species and no specific permissions were required for these locations/activities. The Gulf of Cadiz is an extensive embayment of the Atlantic Ocean from Cape Saint Vincent, Portugal, to the Gibraltar Strait on the southwestern coast of the Iberian Peninsula (Fig. 1). The area is known for its MVs [17-21], and the Ginsburg MV is located within the Western Moroccan MV Field of the gulf. A gravity core was taken and in total $3.55 \mathrm{~m}$ long of mud breccia was recovered from the crater of the MV (water depth ca. 910 m; core M200756) during a MicroSYSTEMS cruise of R/V Pelagia in 2007. The sampling location was the same one from which cores were collected during the TTR-9 (1999) and TTR-10 (2000) cruises

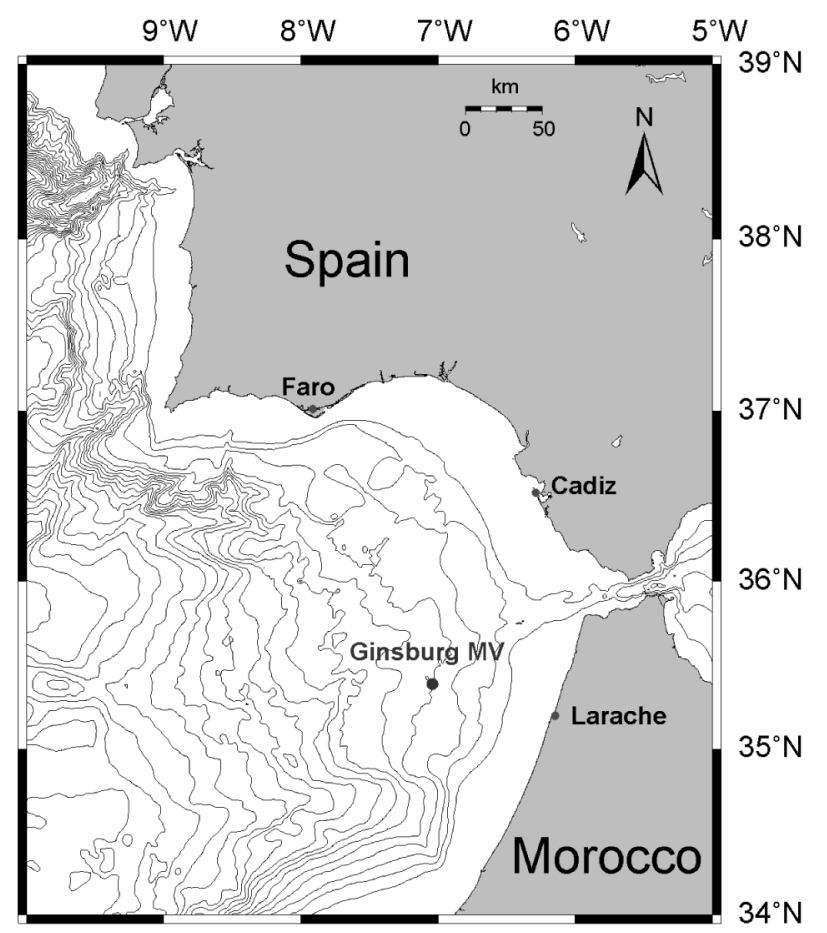

Figure 1. Geological map indicating the location of the Ginsburg MV based on GEBCO (General Bathymetric Chart of the Oceans) bathymetry. The depth difference between two contour lines is $250 \mathrm{~m}$; the closest contour line to the coast represents $250 \mathrm{~m}$ water depth.

doi:10.1371/journal.pone.0113004.g001

undertaken for hydrocarbon gas and lipid biomarker studies $[22,23]$. The lithology, presence of chemosynthetic tube worms at the surface layer and gas hydrates at depths below $1 \mathrm{~m}$ of sediment provided a mirror image of the previously recovered MV deposits taken during several TTR cruises [17,19-21].

\section{Pore water sampling}

The recovered sedimentary core was immediately cut into $1 \mathrm{~m}$ sections and opened in the cold lab container at $+4^{\circ} \mathrm{C}$ for subsampling. Pore water samples were obtained on board at $+4^{\circ} \mathrm{C}$ directly from mud breccia using a Rhizon Core Solution Sampler (Rhizosphere Research Products, Wageningen, the Netherlands). The sampler consisted of a $10 \mathrm{~cm}$ porous polymer tube, which was impermeable to bacteria to maintain the sterility of the samples, connected to a $10 \mathrm{~cm}$ PVG tube and a Luer-Lock connector attached to the standard $10 \mathrm{ml}$ syringe. By drawing the piston, filtered pore waters were collected in the syringe in the vacuum.

To assess sulfate levels, $1 \mathrm{ml}$ of pore water was placed in a plastic vial and kept at $-20^{\circ} \mathrm{C}$. To distinguish stable carbon isotopes from dissolved inorganic carbon $\left(\delta^{13} \mathrm{C}\right.$-DIC), $2 \mathrm{ml}$ of pore water was preserved with $10 \mu \mathrm{l}$ of saturated mercury chlorite solution and stored in darkness at $+4^{\circ} \mathrm{C}$ in gas-tight glass vials without head space. Sulfide was preserved in $5 \mathrm{ml}$ glass vials containing $0.5 \mathrm{ml}$ of pore water and $4.5 \mathrm{ml}$ of $0.1 \mathrm{~N} \mathrm{NaOH}$ solution, which was initially refluxed with $\mathrm{N}_{2}$ for 5 min. Samples with preserved $\mathrm{H}_{2} \mathrm{~S}$ were stored at $+4^{\circ} \mathrm{C}$.

\section{In vitro incubation experiment}

For the incubation experiment, mud breccia samples were collected directly at $4^{\circ} \mathrm{C}$. Sub-sampling was carried out along the total length of the core at $5 \mathrm{~cm}$ intervals using $50 \mathrm{ml}$ plastic sterile 
syringes with cut tips. Samples were immediately sealed in trilaminate PEI aluminum bags (KENOSHA C.V., Amstelveen, the Netherlands) in a nitrogenous atmosphere and stored at $+4^{\circ} \mathrm{C}$ until use.

In off-shore laboratories, the experiments were carried in an anoxic $\mathrm{N}_{2}$ atmosphere in a glove box (Concept 1000, L.E.D. Techno NV, Belgium). In total, 26 sections along the $2.55 \mathrm{~m}$ of the mud breccia section were selected. From each layer, $30 \mathrm{ml}$ of fresh mud volcano deposits were diluted 5 times with artificial seawater medium in a $250 \mathrm{ml}$ Scott bottle closed with a gas-tight butyl stopper. The headspace was first flushed and filled with ${ }^{12} \mathrm{C}-\mathrm{CH}_{4}$ at $0.1 \mathrm{MPa}$ of absolute pressure (the sum of gauge pressure and atmospheric pressure) and then pressurized up to $0.15 \mathrm{MPa}$ of absolute pressure by ${ }^{13} \mathrm{C}_{-}-\mathrm{CH}_{4}$ (99\% Atom, Campro Scientific $\mathrm{GmbH}$, Berlin, Germany). The Scott bottles were placed on a shaker (80 rpm shaking) at $15^{\circ} \mathrm{C}$ in darkness. The total duration of the experiment was 176 days.

\section{Chemical analysis of the incubated samples}

Slurry samples were taken after days 8, 21, 31, 45, 73, 102, 135, and 176 of incubation. At each selected interval, approximately $3 \mathrm{ml}$ of slurry was collected through a syringe without open the bottle, completely filled into two $1.5 \mathrm{ml}$ Eppendorf tubes (Eppendorf, Hamburg, Germany), and centrifuged at 13,200 $\mathrm{g}$ for $2 \mathrm{~min}$. The supernatant was collected and used for the determination of dissolved sulfide, sulfate and $\mathrm{pH}$ according to a previously described method [24]. The residue $(\sim 1.3 \mathrm{ml}$ in each tube) was frozen at $-20^{\circ} \mathrm{C}$ for future DNA extraction.

Gas analysis was performed on samples incubated for 8 and 176 days. The gas pressure inside the incubation bottle was measured with an INFIELD 7C Tensiometer (UMS, München, Germany). From each incubation bottle, $0.5 \mathrm{ml}$ of gas was removed and immediately injected into a $12 \mathrm{ml}$ vacuumed gas sampling tube (Labco Limited, Buckinghamshire, UK). Next, the gas sampling tube was filled with helium up to atmospheric pressure. The $\mathrm{CO}_{2}$ concentration (including both ${ }^{13} \mathrm{C}-\mathrm{CO}_{2}$ and ${ }^{12} \mathrm{C}-\mathrm{CO}_{2}$ ) was quantified using a gas chromatograph (GC 14B, Shimadzu Corporation, Kyoto, Japan) equipped with a $2 \mathrm{~m}$ Porapak Q column (0.3 cm o.d., SS 80/100) and a pre-column (1 m) of the same material (both at $35^{\circ} \mathrm{C}$ ) and a ${ }^{63} \mathrm{Ni}$ electron capture detector $(\mathrm{ECD})$ at $250^{\circ} \mathrm{C}$. The ratio between ${ }^{13} \mathrm{C}-\mathrm{CO}_{2}$ and ${ }^{12} \mathrm{C}-\mathrm{CO}_{2}$ was quantified with an isotope ratio mass spectrometer (IRMS 20-20, Sercon Ltd, Cheshire, UK) coupled to a GC in a climatized room $\left(21.0 \pm 0.5^{\circ} \mathrm{C}\right)$ using the same technical settings as described previously [25].

\section{In vitro $\mathrm{AOM}$ and $\mathrm{SR}$ rate calculations}

Both AOM and SR rates were expressed as nmol sulfide $/ \mathrm{CO}_{2}$ production per $\mathrm{ml}$ of fresh sediment per day $(\mathrm{nmol} / \mathrm{ml} \mathrm{rs} / \mathrm{d})$. The turnover rate was calculated according to the following formula:

$$
S R=\frac{\text { sulfide produced }}{\text { incubation time } * \text { liquid volume }}
$$

For the AOM rate calculation, the total production of ${ }^{13} \mathrm{C}$-carbon species, i.e., ${ }^{13} \mathrm{C}-\mathrm{CO}_{2}$ in both liquid and gas phases, ${ }^{13} \mathrm{C}-\mathrm{HCO}_{3}{ }^{-}$ and ${ }^{13} \mathrm{C}-\mathrm{H}_{2} \mathrm{CO}_{3}$ in liquid phase, was first calculated. Given that $1 / 3$ of the initial headspace consisted of ${ }^{13} \mathrm{C}-\mathrm{CO}_{2}$ and $2 / 3$ consisted of ${ }^{12} \mathrm{C}_{1}-\mathrm{CO}_{2}$, the overall AOM rate was calculated as follows:

$$
A O M=\frac{{ }^{13} \text { C carbonate species produced }}{\text { incubation time } * \text { liquid volume }} * 3
$$

\section{Prokaryotic community analysis of the incubated samples}

DNA extraction. DNA extraction was performed on the samples taken on day 0 and day 176 at each sediment depth, in total 52 samples. The residue after chemical analysis was thaw and mixed, from which a $0.5 \mathrm{ml}$ slurry was used to extract DNA using Fast DNA Spin Kit for soil (Bio 101, Q-Biogene, Heidelberg, Germany) according to the manual supplied with the kit. The raw DNA was then purified with a DNA Purification Kit (Wizard, Promega, Madison, USA) and eluted to a final volume of $50 \mu \mathrm{l}$.

Terminal restriction fragment length polymorphism ( $T$ RFLP) of the prokaryotic community. To amplify bacteria, the primers 27f-FAM and 907r (Table 1) were used under the condition described in Table $\mathrm{S} 1$ and Table S2. The obtained PCR product was purified with a PCR purification kit (Qiagen, Hilden, Germany) and eluted to a final volume of $30 \mu \mathrm{l}$. The DNA concentration in the PCR products was quantified using a NanoDrop ND-1000 Spectrophotometer (Thermo Scientific, Wilmington, USA). Then, $100 \mathrm{ng}$ of the purified PCR product was added to Tango buffer (Fermentas, Burlington, Canada) and digested with 2.5 units of restriction enzyme $\mathrm{Mspl}$ at $37^{\circ} \mathrm{C}$ for 3 hours. After digestion, $100 \mu \mathrm{l}$ cold ethanol (95\%) was added, and the sample was incubated at $4^{\circ} \mathrm{C}$ for $30 \mathrm{~min}$ to precipitate the digested DNA fragments. Subsequently, the samples were centrifuged at $14,000 \mathrm{~g}$ for $30 \mathrm{~min}$. The pellet obtained from the precipitation was further washed with $100 \mu \mathrm{l}$ cold ethanol $(75 \%)$ and centrifuged at $14,000 \mathrm{~g}$ for $10 \mathrm{~min}$. The supernatant was discharged, and the pellet was vacuum dried for 5 min using Savant SpeedVac DNA 110 (GMI, Minnesota, USA).

To amplify archaea, a nested PCR approach was applied. The first PCR was run with primers Arch21f/Uni1392r (Table 1) under the condition described in Table S1 and Table S3. The nested PCR was run with the primers Arch21f-FAM and Arch958r (Table 1) using the product from the first PCR as a template under the condition described in Table S1 and Table S4. The products were assayed on a $1 \%$ agarose gel. Bands of the correct length on the gel were cut and purified using the QIAquick Gel Extraction Kit (Qiagen, Hilden, Germany). The PCR product $(100 \mathrm{ng})$ obtained from gel extractions was digested by 2.5 units of restriction enzyme Hhal at $37^{\circ} \mathrm{C}$ for 3 hours. The digested DNA fragments were then washed and dried according to the procedure as described above.

The resultant DNA fragments with fluorescent labels were analyzed at the Genetic Service Unit (University Hospital, Gent, Belgium). Statistical analysis of the patterns was performed using Bionumerics 5.1 software (Applied Maths, Sint-Martens-Latem, Belgium) [26].

Extracted data were processed for ecological interpretation in the following aspects:

1) Richness - the number of bands in one T-RFLP pattern was used an indicator of community richness.

2) Community organization (Gini) - calculated from the normalized area between a given Lorenz curve and the perfect evenness line [26]. This calculation yields a single value used to describe the degree of evenness of the community. 
Table 1. Primers and probes used in this study.

\begin{tabular}{|c|c|c|c|}
\hline Name (labeling) & Sequence $\left(5^{\prime}\right.$ to $\left.3^{\prime}\right)$ & Specificity & References \\
\hline \multicolumn{4}{|l|}{ primer } \\
\hline Arch-21f & TTC CGG TTG ATC CYG CCG GA & Archaea & [37] \\
\hline Arch-21f-FAM & FAM-TTC CGG TTG ATC CYG CCG GA & Archaea & Modified from [37] \\
\hline 27f-FAM & 6-FAM-AGA GTT TGA TCC TGG CTC AG & Bacteria & [38] \\
\hline $907 r$ & CCG TCA ATT CCT TTR AGT TT & Bacteria & [38] \\
\hline Arch-958r & YCC GGC GTT GAM TCC AAT T & Archaea & [37] \\
\hline Uni-1392r & ACG GGC GGT GTG TRC & Universal & [39] \\
\hline \multicolumn{4}{|l|}{ probe } \\
\hline ANME1-350 & AGT TTT CGC GCC TGA TGC & ANME-1 archaea & [40] \\
\hline EelMS932 & AGC TCC ACC CGT TGT AGT & ANME-2 archaea & [40] \\
\hline ANME3-1249 & TCG GAG TAG GGA CCC ATT & ANME-3 archaea & [41] \\
\hline ANME3-1249H3 & GTC CCA ATC ATT GTA GCC GGC & Helper probe for ANME3-1249 & [42] \\
\hline ANME3-1249H5 & TTA TGA GAT TAC CAT CTC CTT & Helper probe for ANME3-1249 & [42] \\
\hline DSS658 & TCC ACT TCC CTC TCC CAT & $\begin{array}{l}\text { Desulfosarcina spp., Desulfofaba spp., } \\
\text { Desulfococcus spp., Desulfofrigus spp. }\end{array}$ & [43] \\
\hline
\end{tabular}

doi:10.1371/journal.pone.0113004.t001

3) Similarity via depth - used to describe the rate of community changes with sediment depth using moving window analyses [26]. The value presented is the similarity of T-RFLP patterns of two samples from the sediment depths next to each other. For example, the T-RFLP pattern of sediment sample at $20 \mathrm{~cm}$ bsf was compared to that of sediment sample at $10 \mathrm{~cm}$ bsf, and the similarity is shown as a unit of percentage in $y$ axil.

\section{Cell identification and quantification of the incubated samples}

The mud breccia slurry samples from the incubation experiment were taken at days 0 and 176 and fixed in $4 \%$ formaldehyde (1 part slurry to 3 parts formaldehyde) overnight at $4{ }^{\circ} \mathrm{C}$. The fixed sample was then washed with PBS buffer twice and further diluted 2000 times with PBS. Next, $8 \mathrm{ml}$ diluted slurry was filtered onto a circular GTTP polycarbonate filter $(0.2 \mu \mathrm{m}$, Millipore, Germany) with a diameter of $2.5 \mathrm{~cm}$. Cell staining and catalyzed reporter deposition fluorescence in situ hybridization (CARD-FISH) analysis were performed on the filter based on the protocol of Pernthaler et al [27]. DAPI (4',6'-diamidino-2-phenylindol) staining was used to assess the total cell count. The probes used to identify ANME groups and SRB are listed in Table 1. Cells were counted under a microscope (Zeiss, Carl Zeiss Microimaging $\mathrm{GmbH}$, Germany) with 50 fields of view $(140 \mu \mathrm{m} * 90 \mu \mathrm{m})$ used for each hybridization. The detection limit of this method was $2 * 10^{5}$ cell (aggregate) $/ \mathrm{ml}$ raw sediment.

\section{Results}

\section{Field observations and pore water profile}

The sediment core from the Ginsburg MV reached $904 \mathrm{~m}$ of water depth and recovered $357 \mathrm{~cm}$ of sediment. When the core was cut open, voids, most likely from the decomposition of gas hydrates, were observed at depths of $53-58 \mathrm{~cm}, 111-113 \mathrm{~cm}$, $128-133 \mathrm{~cm}, 173 \mathrm{~cm}, 193 \mathrm{~cm}$, and 213-218 cm bsf. A thin layer consisting of a few $\mathrm{mm}$ of hemipelagic trapping was observed on the surface.
In the pore water, sulfide was detected at $34-141 \mathrm{~cm}$ bsf (maximum $11.2 \mathrm{mM}$ ) and at $193 \mathrm{~cm}$ bsf (maximum $2.6 \mathrm{mM}$ ) (Fig. 2A). The sulfate concentration decreased from ambient seawater levels (i.e., $28.0 \mathrm{mM}$ ) to $4.0 \mathrm{mM}$ within the top $12 \mathrm{~cm}$ of sediment and remained stable until $307 \mathrm{~cm}$ bsf; below this depth, a sharp increase was observed (Fig. 2B). The seawater chloride concentration $(544 \pm 2 \mathrm{mM})$ was measured in the top $12 \mathrm{~cm}$ of sediment. The chloride concentrations varied from 431 to $627 \mathrm{mM}$ in the top $34 \mathrm{~cm}$ and remained relatively stable until $297 \mathrm{~cm}$ bsf, with an average value of $528 \pm 21 \mathrm{mM}$ (Fig. 2C).

\section{In vitro SR-AOM activity at different depths}

When methane and sulfate were supplied, sediments from different depths responded differently in terms of SR-AOM activities. Throughout the 176 days of the incubation period, two distinguishable active zones were formed. A shallow active zone was defined at $30-55 \mathrm{~cm}$ bsf in which the sediments only showed low SR activity after 102 days of incubation (Fig. 3). The overall SR activities during the 176-day incubation period were in the range of $0.3-1.4 \mathrm{nmol} / \mathrm{ml} \mathrm{rs} / \mathrm{d}$. When the $\mathrm{SR}$ was calculated between day 102 (when sulfide production was observed) and day 176 (the end point of the incubation), the rates were in the range of 0.6-3.2 $\mathrm{nmol} / \mathrm{ml} \mathrm{rs} / \mathrm{d}$. No detectable AOM activity was observed in these samples.

A deeper AOM active zone was defined at 165-205 cm bsf. In the presence of methane and sulfate, this interval exhibited an immediate production of sulfide, which remained active throughout the incubation experiment (Fig. 3). The highest SR activity, $24.7 \mathrm{nmol} / \mathrm{ml} \mathrm{rs} / \mathrm{d}$, was detected at a depth of $195 \mathrm{~cm}$ bsf. This sediment layer also showed AOM activity, with rates of 1.4$6.2 \mathrm{nmol} / \mathrm{ml} \mathrm{rs} / \mathrm{d}$ (Fig. 4A). The remainder of the mud breccia section revealed no SR or AOM activities (Fig. 3).

\section{Community structure and dynamics}

During the incubation experiment, diverse bacterial communities were described throughout the mud breccia sample at different sediment depths (Fig. 4B). Throughout the incubation period, the average bacterial communities' similarity via depth increased from $68 \%$ at day 0 to $81 \%$ at day 176 . After incubation, the average 


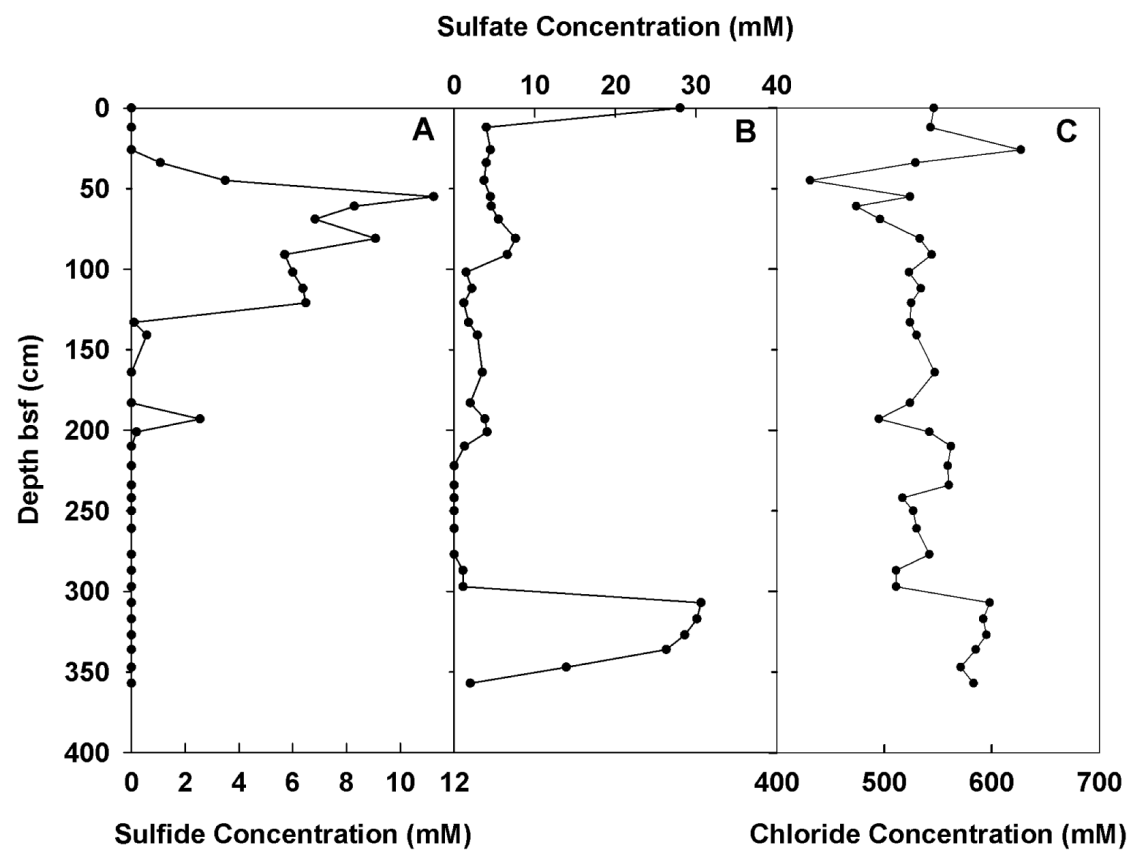

Figure 2. The concentrations of ions, including sulfide (A), sulfate (B) and chloride (C), in the pore water of the Ginsburg MV. doi:10.1371/journal.pone.0113004.g002

bacterial communities' similarity via depth of a mud breccia sample covering the interval of $55 \mathrm{~cm}-205 \mathrm{~cm}$ bsf reached $90 \%$. Fig. 4C shows that the uppermost $40 \mathrm{~cm}$ exhibited moderate bacterial evenness (Gini), and these values increased with increasing depth especially after incubation. In contrast, Fig. 4D shows that bacterial richness decreased with increasing depth within the top $75 \mathrm{~cm}$ both before and after incubations.
Archaeal T-RFLP patterns could only be obtained from the uppermost $65 \mathrm{~cm}$ of sediment because that concentrations of archaeal cells are below the detection limit of the method applied in the present work. Compared with bacterial communities, archaeal communities showed much lower richness (Fig. 4G).

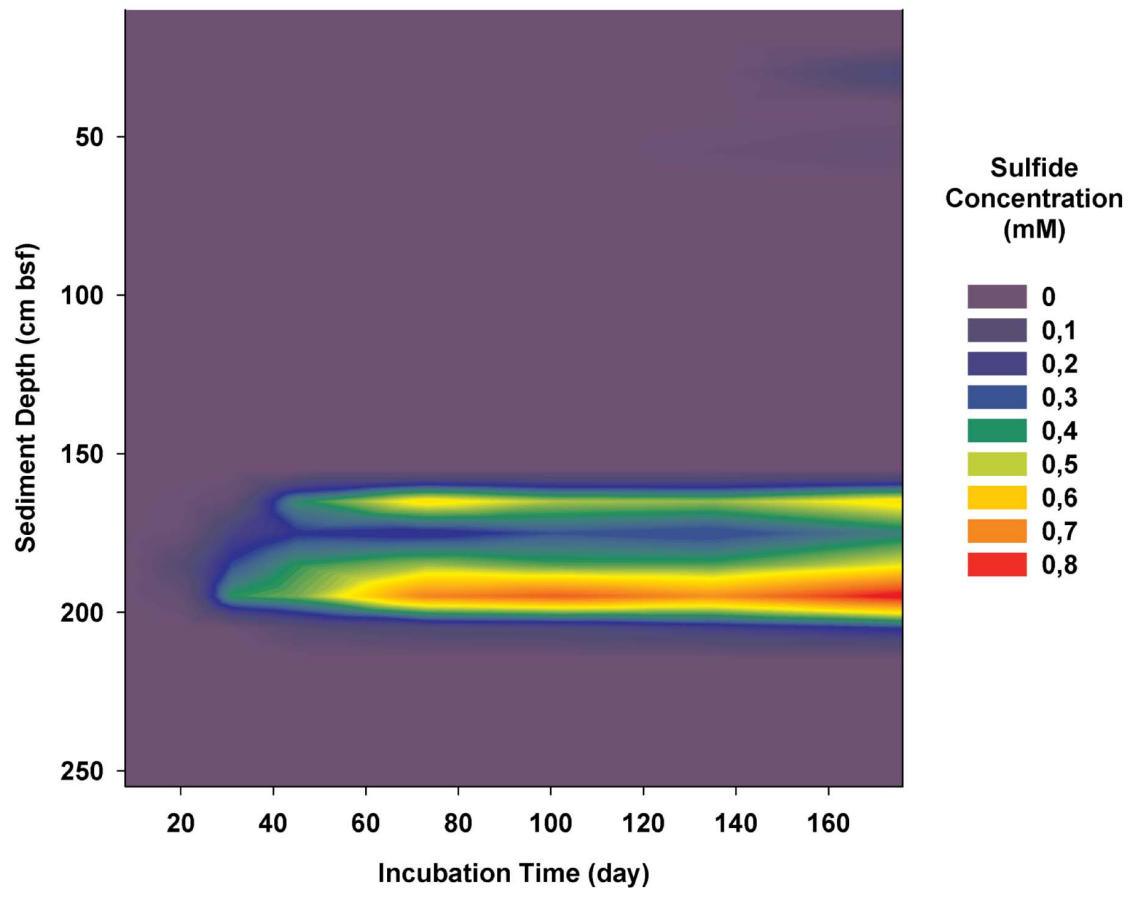

Figure 3. Cumulative sulfide concentrations at different sediment depths during 176 days of in vitro incubation with a methane and sulfate supply.

doi:10.1371/journal.pone.0113004.g003 


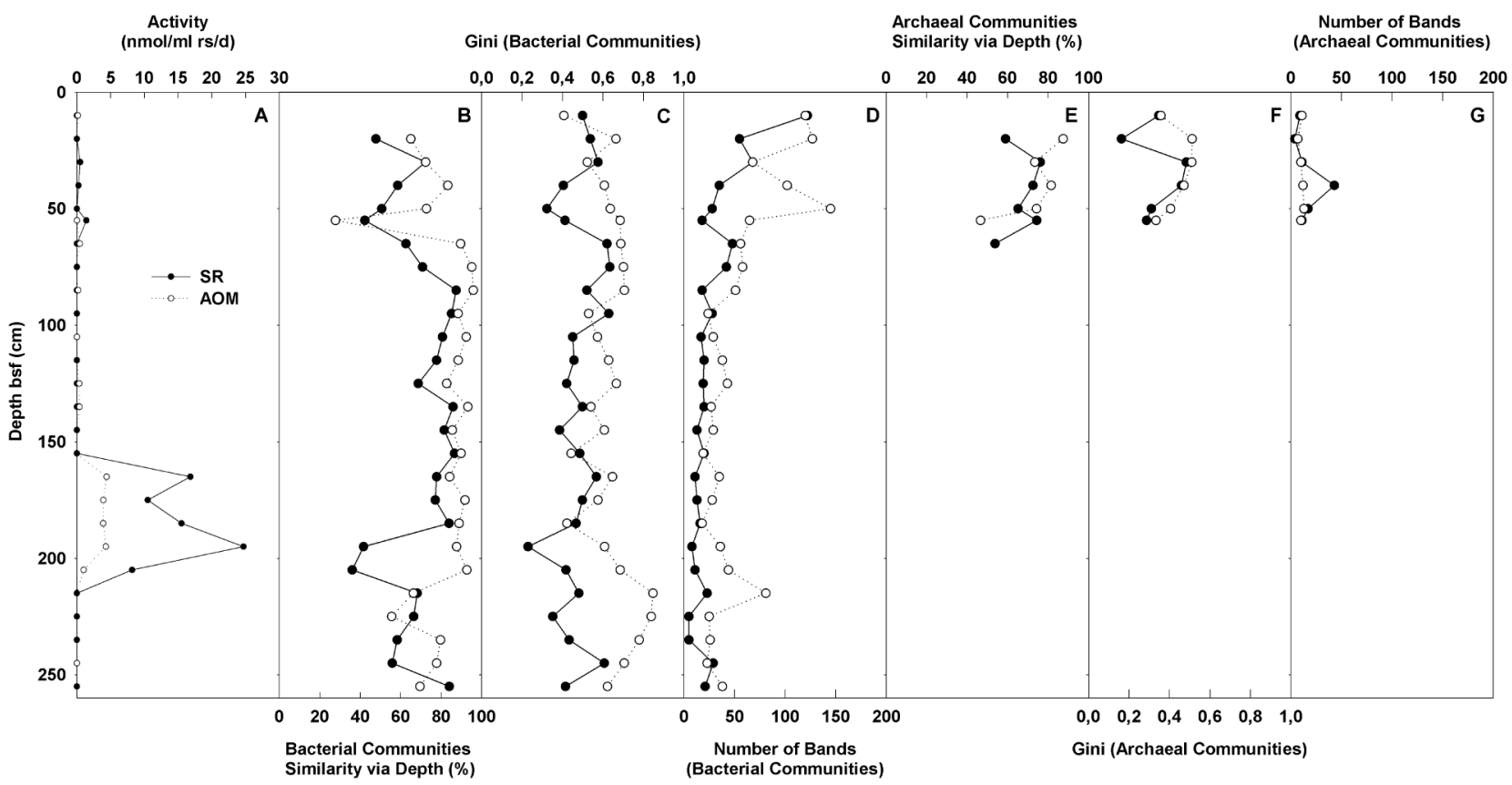

Figure 4. The microbial activity and community structures as an effect of 176 days of in vitro incubation. A) The overall SR/AOM activities; B/E) the bacterial/archaeal communities' similarity with respect to sediment depth; C/F) the bacterial/archaeal communities' evenness expressed as a Gini value; D/G) the bacterial/archaeal communities' richness. Legend for A: the solid dot is the SR rate, and the circle is the AOM rate. Legend for B-G: the solid dot is the value at day 0 , and the circle is the value at day 176.

doi:10.1371/journal.pone.0113004.g004

\section{Cell quantification and identification}

Cell counts based on DAPI staining demonstrated that the cell concentration in the shallow active zone (i.e., sediment from $55 \mathrm{~cm} \mathrm{bsf}$ ) was one log unit higher than that in the deeper active zone (i.e., sediment from $195 \mathrm{~cm}$ bsf) (Table 2). After incubation, a $70 \%$ decrease in total biomass was found at a sediment depth of $55 \mathrm{~cm}$ bsf. Here, the abundance of ANME-1 cells remained constant, and their relative concentration increased from $6 \%$ before to $20 \%$ after the incubation. The ANME-2 and SRB contents were just above the detection limit, and ANME-3 cells were not detected. In contrast, the incubation had no effect on total cell numbers in mud breccia at $195 \mathrm{~cm}$ bsf but clearly stimulated the growth of ANME-2 and SRB, especially in the form of aggregates (diameter 2-10 $\mu \mathrm{m}$ ) (Table 2).

\section{Discussion}

\section{Multiple AOM active zones}

The Ginsburg MV is located in the eastern part of Gulf of Cadiz (Fig. 1), an active MV and fluid-venting region [23,28]. Mud breccia was collected from a relatively recent mudflow and it contained gas hydrates; the presence of gas hydrates is a known phenomenon for this MV [23]. For the last decade, the Ginsburg MV has been reported as an active structure, and its tectonic structure and geobiochemistry have been intensively studied by

Table 2. Cell identification and quantification by CARD-FISH.

\begin{tabular}{|c|c|c|c|c|c|}
\hline \multirow[t]{2}{*}{$\begin{array}{l}\text { Prokaryotic group } \\
\text { targeted }\end{array}$} & \multirow{2}{*}{ cell (aggregate)/ml } & \multicolumn{2}{|l|}{$55 \mathrm{~cm}$ bsf } & \multicolumn{2}{|l|}{$195 \mathrm{~cm}$ bsf } \\
\hline & & Before incubation & After incubation & Before incubation & After incubation \\
\hline \multirow[t]{2}{*}{ Total } & Cell & $1 * 10^{8}$ & $3^{*} 10^{7}$ & $8^{*} 10^{6}$ & $8^{*} 10^{6}$ \\
\hline & Aggregate & $5 * 10^{5}$ & $6 * 10^{5}$ & $9^{*} 10^{5}$ & $2^{*} 10^{6}$ \\
\hline \multirow[t]{2}{*}{ ANME-1 } & Cell & $6^{*} 10^{6}$ & $6^{*} 10^{6}$ & $<2^{*} 10^{5}$ & $2^{*} 10^{5}$ \\
\hline & Aggregate & $<2 * 10^{5}$ & $<2 * 10^{5}$ & $<2 * 10^{5}$ & $<2 * 10^{5}$ \\
\hline \multirow[t]{2}{*}{ ANME-2 } & Cell & $2^{*} 10^{5}$ & $4^{*} 10^{5}$ & $2^{*} 10^{5}$ & $<2^{*} 10^{5}$ \\
\hline & Aggregate & $<2^{*} 10^{5}$ & $<2 * 10^{5}$ & $<2^{*} 10^{5}$ & $8 * 10^{5}$ \\
\hline \multirow[t]{2}{*}{ ANME-3 } & Cell & $<2^{*} 10^{5}$ & $<2^{*} 10^{5}$ & $<2 * 10^{5}$ & $<2 * 10^{5}$ \\
\hline & Aggregate & $<2^{*} 10^{5}$ & $<2 * 10^{5}$ & $<2^{*} 10^{5}$ & $<2^{*} 10^{5}$ \\
\hline \multirow[t]{2}{*}{ SRB } & Cell & $<2^{*} 10^{5}$ & $<2^{*} 10^{5}$ & $<2 * 10^{5}$ & $2 * 10^{5}$ \\
\hline & Aggregate & $<2^{*} 10^{5}$ & $<2^{*} 10^{5}$ & $<2^{*} 10^{5}$ & $1 * 10^{6}$ \\
\hline
\end{tabular}

doi:10.1371/journal.pone.0113004.t002 
different programs and scientific groups [17,21-23,29-31]. In the present study, the sulfide and sulfate distribution profiles identifies the location of the SMTZ at a depth of 30-70 cm bsf (Fig. 2). This result is in agreement with published data on hydrocarbon gases, pore water parameters and AOM/SR rates measurements from the same MV [23,31]. Meanwhile, Figs. 2B and 2C show that at a depth of ca. $190 \mathrm{~cm}$ bsf, the behavior of sulfide and sulfate curves indicates the possibility of an additional AOM active zone. The sulfate profile clearly suggests an alternative to the seawater sulfate source, the nature of which has thus far not been elucidated. The occurrence of specific void-like structures resulting from the dissociation of gas hydrates was also documented within the same mud breccia interval. Accordingly, pore water parameters suggest two potentially active AOM intervals within the uppermost $2.5 \mathrm{~m}$ of mud breccia.

The evidence of two separate active AOM zones is also supported by the in vitro incubation experiment in which additional methane and sulfate were supplied. Under these conditions, immediate and/or delayed SR was detected within similar sedimentary layers, i.e., at $30-55 \mathrm{~cm}$ bsf and at 165$205 \mathrm{~cm}$ bsf. Furthermore, despite the low sulfide concentrations in the pore water, mud breccia from the deep AOM zone showed immediate SR and AOM activity that was ten times higher than the activity in the AOM interval above (Fig. 4A). Therefore, the vertical distribution profiles of pore water form a valuable tool for targeting the potential AOM active zones but are not necessarily sufficient to quantify the rates of the process. Although measured in vitro activity is strongly affected by the incubation conditions, in vitro measurements remain a valuable indicator for understanding in situ microbial activity. We are aware that in this study, the incubation was performed as single microcosms without replicates due to the biomass limitation, which may cause bias. Still, the sediment depths with AOM activity were clustered into two intervals, which is strong evidence to locate the AOM active zones. The in vitro experiments led to the hypothesis that, in the presence of necessary electron donors and acceptors, anaerobic methanotrophy can be fuelled and sustained even at great sedimentary depths.

The discovery of multiple AOM active intervals in one sediment core suggests that deep AOM activity should not be overlooked in methane budget calculations. Based on the currently available data, the sources and sinks of oceanic methane are not balanced with the standing stock. For example, according to the estimated data from Reeburgh [10], the reciprocal of the measured and modeled specific turnover rates for the deep ocean (0.01-0.02 year $^{-1}$ ) provides a residence time based on a removal time of 50 100 years. In contrast, dividing the open ocean standing stock $\left(43.2 \mathrm{Tg}\right.$ ) by estimated methane fluxes from MVs $\left(27 \mathrm{Tg}_{\text {year }}{ }^{-1}\right)$ and shelf additions $\left(20 \mathrm{Tg}_{\text {year }}{ }^{-1}\right.$ ) yields an estimated residence time of between 2 and 3 years based on the addition of methane. These data on methane turnover rate to calculate the budget were often generated from in situ or in vitro radioactive tracer incubations, which is a sensitive method but is restricted to surface sediment and short-term monitoring. Deep or delayed methanotrophic processes have therefore been largely ignored. Based on the experimental data in this study, the deep layer AOM activity is one order of magnitude higher than that in SMTZ. This deep buried methane sink could at least partially reconcile the gap of current methane budget.

\section{Response of ANMEs to methane and sulfate supply}

Although ANME lipid biomarkers, especially ANME-1, appeared to be present in every interval of the Ginsburg MV core down to $180 \mathrm{~cm}$ bsf [23], both the pore water profile and our incubation results lead to the conclusion that AOM activity is only present at certain sediment depths. It is not surprising that sediments all along the sampling core might have been exposed to a methane- and sulfate-rich environment during certain historical periods because the discharge of hydrocarbon-rich fluid is a common phenomenon in the Gulf of Cadiz and the Ginsburg MV is characterized as an active structure with extensive mud diapirism and mud volcanism. The relatively broad distribution of ANME lipids along the MV deposits indirectly indicates methane flow and, thus, a migration or displacement of the SMTZ in the Ginsburg MV [23]. The AOM microbial activity in recent or ancient SMTZs cannot be always restored within a six month period simply by providing fresh methane and sulfate in laboratory conditions, implying that the in situ development of the AOM community after methane- and sulfate-rich fluid migration is a long-term process.

The incubation conditions in this study apparently favor the activity and growth of ANME-2 over ANME-1. An increase in ANME-2 cells and aggregates has been observed in both of the AOM active zones. Moreover, sediment from the deeper location, in which ANME-2 is dominant, has higher SR-AOM activity compared with that from the SMTZ, where ANME-1 is dominant. In fact, in addition to ANME-2, ANME-1 has been selectively enriched in the SMTZ; the ANME-1 cell numbers remained constant, whereas there was a $70 \%$ decay of total freeliving cells (counted by DAPI staining, Table 2). Alternatively, this $70 \%$ decay of cells might have contributed to heterotrophic SR and other microbial processes; however, we did not measure such processes. This incubation result is in agreement with investigations from other researchers regarding the niche differentiation of ANME-1 and ANME-2. For example, it has been suggested that compared to ANME-1, ANME-2 is dominant in environments with higher SR activity, lower flow rates, relatively elevated methane partial pressures and temperatures in the range of 10$15^{\circ} \mathrm{C}$ [32-34]; such a pattern is similar to what we observed in our incubations, especially in the deeper active zone.

\section{Community response to in vitro incubations}

The incubation promoted a tendency for prokaryotic communities, especially bacterial communities, at different depths to converge (Figs. 4B and 4E). Concurrently, the bacterial community richness also rose as a result of the incubation, even in sediment intervals without detectable SR activity (Fig. 4D). The entire incubation period lasted 176 days, at which point there was almost no overpressure inside certain incubation bottles; methane gas had been consumed by microorganisms and lost during sampling. During the incubation period, the ANME and SRB cells reproduced 1-3 times (calculated from the data in Table 2). Due to the extremely low growth rates of ANME and SRB (with doubling times of approximately 2 months), they are not major contributors in terms of abundance to overall prokaryotic community dynamics despite the fact that they are key players in primary production in the cold seep ecosystem. The rapid changes in community structure and the increase in richness are thought to be driven by the increase of substrate diversity during incubation [35]. Initially, methane and $\mathrm{CO}_{2}$ were the only sources of additional carbon; later, the metabolic products of ANME and $\mathrm{SRB}$ and the decay of biomass allowed more complex carbon compounds to become available to the system. It must be taken into account that, due to the low biomass content from our samples, this T-RFLP analysis is unlikely to capture rare species. It has been proven that when a preconditioned community colonizes a familiar habitat, the community structure is more predictable [36]. It is therefore reasonable to believe that the species that were 
observed to increase using T-RFLP were also historically dominant. The increase of biodiversity suggests that a more complex metabolic network within local ecosystems was stimulated due to the incubation, whereas the increase in similarity via depth suggests that the metabolic networks at different sediment depths share similar groups of microbes. Future work with higher efficiency and sequencing data, which may be accomplished by using pyrotags, could detail such communities and their functions.

\section{Concluding Remarks}

In this study, we attempted to identify how the prokaryotic community would respond to changes in methane and sulfate intensities in Ginsburg MV sediment. After a long-term in vitro incubation, a deeply buried AOM active zone was discovered besides the SMTZ, where the AOM activity was one order of magnitude higher than that of SMTZ. This discovery calls up our attention that the potential AOM activity at deep subsurface even below SMTZ should not be ignored or underestimated in oceanic methane budget calculation. Moreover, the incubation condition, a highly reduced environment with high sulfate and methane concentration but no flux nor organic nutrient supply, caused a selective enrichment of ANME (especially ANME-2 rather than ANME-1) and SRB. Although ANME-2 and SRB are the main contributors to SR-AOM activity, bacteria, who may be living on the organic compounds released from cellular metabolism and decay, are taking the major part to shape the overall community structure. This study provides direct information regarding to the spatial distribution and activity of archaea and bacteria in cold seep environments.

\section{References}

1. ZoBell CE, Anderson DQ (1936) Vertical distribution of bacteria in marine sediments. AAPG Bulletin 20: 258-269.

2. Parkes RJ, Cragg BA, Bale SJ, Getliff JM, Goodman K, et al. (1994) Deep bacterial biosphere in Pacific Ocean sediments. Nature (London) 371: 410-413.

3. Kallmeyer J, Pockalny R, Adhikari RR, Smith DC, D'Hondt S (2012) Global distribution of microbial abundance and biomass in subseafloor sediment. Proceedings of the National Academy of Sciences of the United States of America 109: 16213-16216.

4. Parkes RJ, Webster G, Cragg BA, Weightman AJ, Newberry CJ, et al. (2005) Deep sub-seafloor prokaryotes stimulated at interfaces over geological time. Nature 436: 390-394.

5. Whitman WB, Coleman DC, Wiebe WJ (1998) Prokaryotes: The unseen majority. Proceedings of the National Academy of Sciences of the United States of America 95: 6578-6583.

6. Jorgensen BB (2012) Shrinking majority of the deep biosphere. Proceedings of the National Academy of Sciences of the United States of America 109: 1597619577.

7. Coolen MJ, Cypionka H, Sass AM, Sass H, Overmann J (2002) Ongoing modification of Mediterranean Pleistocene sapropels mediated by prokaryotes. Science 296: 2407-2410

8. Borin S, Brusetti L, Mapelli F, D’Auria G, Brusa T, et al. (2009) Sulfur cycling and methanogenesis primarily drive microbial colonization of the highly sulfidic Urania deep hypersaline basin. Proc Natl Acad Sci U S A 106: 9151-9156.

9. Parkes RJ, Sellek G, Webster G, Martin D, Anders E, et al. (2009) Culturable prokaryotic diversity of deep, gas hydrate sediments: first use of a continuous high-pressure, anaerobic, enrichment and isolation system for subseafloor sediments (DeepIsoBUG). Environ Microbiol 11: 3140-3153.

10. Reeburgh WS (2007) Oceanic methane biogeochemistry. Chemical Reviews 107: 486-513.

11. Kruger M, Meyerdierks A, Glockner FO, Amann R, Widdel F, et al. (2003) A conspicuous nickel protein in microbial mats that oxidize methane anaerobically. Nature 426: 878-881.

12. Hallam SJ, Putnam N, Preston CM, Detter JC, Rokhsar D, et al. (2004) Reverse methanogenesis: Testing the hypothesis with environmental genomics. Science 305: 1457-1462.

13. Pernthaler A, Dekas AE, Brown CT, Goffredi SK, Embaye T, et al. (2008) Diverse syntrophic partnerships from deep-sea methane vents revealed by direct cell capture and metagenomics. Proc Natl Acad Sci U S A 105: 7052-7057.

14. Knittel K, Boetius A (2009) Anaerobic oxidation of methane: progress with an unknown process. Annu Rev Microbiol 63: 311-334.

15. Stadnitskaia A (2007) Bio- and Petroleum Geochemistry of Mud Volcanoes in the Sorokin Trough (NE Black Sea) and in the Gulf of Cadiz (NE Atlantic):

\section{Supporting Information}

Table S1 Reagents concentrations for bacterial and archaeal PGR using KAPA2G Robust PGR kit (KAPA Biosystems, Wilmington, USA).

(DOCX)

Table S2 Thermal protocol for bacterial PGR using primer set $27 f-F A M / 907$ r.

(DOCX)

Table S3 Thermal protocol for archaeal PCR using primer set Arch21f/Uni1392r.

(DOCX)

Table S4 Thermal protocol for archaeal PGR using primer set Arch21f-FAM/Arch958r.

(DOCX)

\section{Acknowledgments}

We acknowledge shipboard scientific party and ship crew from R. V. Pelagia cruise M2007 (64PE268) for the sediment sampling. We thank Tim Lacoere for technical support on molecular analysis, Jan Vermeulen for technical support on gas analysis and Lies de Mol for making the geological map.

\section{Author Contributions}

Conceived and designed the experiments: YZ LM NB. Performed the experiments: YZ. Analyzed the data: YZ LM AS. Contributed reagents/ materials/analysis tools: PB. Wrote the paper: YZ AS XX NB.

From Fluid Sources to Microbial Methane Oxidation and Carbonate Formation. Utrecht: Universiteit Utrecht.

16. Akhmanov GG, Woodside JM (1998) Mud Volcanic samples in the context of the Mediterranean Ridge mud diapiric belt. In: Robertson AHF, Emeis K-C, Richter C, Camerlenghi A, editors. Proc ODP, Sci Results, 160: College Station, TX (Ocean Drilling Program). Texas.

17. Gardner JM (2001) Mud volcanoes revealed and sampled on the Western Moroccan continental margin. Geophysical Research Letters 28: 339-342.

18. Ivanov MK, Pinheiro LM, Stadnitskaia A, Blinova V (2001) Hydrocarbon seeps on deep portuguese margin; Strasbourg.

19. Kenyon NH, Ivanov MK, Akhmetwhanov AM, Akhmanov GG (2000) Multidisciplinary study of geological processes on the North East Atlantic and Western Mediterranean Margins. Paris.

20. Kenyon NH, Ivanov MK, Akhmetwhanov AM, Akhmanov GG (2001) Geological Processes in the Mediterranean and Black Seas and North East Atlantic. Paris.

21. Pinheiro LM, Ivanov MK, Sautkin A, Akhmanov G, Magalhaes VH, et al. (2003) Mud volcanism in the Gulf of Cadiz: results from the TTR-10 cruise. Marine Geology 195: 131-151.

22. Stadnitskaia A, Ivanov MK, Blinova V, Kreulen R, van Weering TCE (2006) Molecular and carbon isotopic variability of hydrocarbon gases from mud volcanoes in the Gulf of Cadiz, NE Atlantic. Marine and Petroleum Geology 23: 281-296.

23. Stadnitskaia A, Ivanov MK, Damste JSS (2008) Application of lipid biomarkers to detect sources of organic matter in mud volcano deposits and post-eruptional methanotrophic processes in the Gulf of Cadiz, NE Atlantic. Marine Geology 255: 1-14.

24. Zhang Y, Henriet JP, Bursens J, Boon N (2010) Stimulation of in vitro anaerobic oxidation of methane rate in a continuous high-pressure bioreactor. Bioresource Technology 101: 3132-3138.

25. Beheydt D, Boeckx P, Clough TJ, Vermeulen J, Sherlock RR, et al. (2005) Methods to adjust for the interference of $\mathrm{N} 2 \mathrm{O}$ on delta C-13 and delta O-18 measurements of $\mathrm{CO} 2$ from soil mineralization. Rapid Communications in Mass Spectrometry 19: 1365-1372.

26. Marzorati M, Wittebolle L, Boon N, Daffonchio D, Verstraete W (2008) How to get more out of molecular fingerprints: practical tools for microbial ecology. Environmental Microbiology 10: 1571-1581.

27. Pernthaler A, Pernthaler J, Amann R (2002) Fluorescence in situ hybridization and catalyzed reporter deposition for the identification of marine bacteria. Applied and Environmental Microbiology 68: 3094-3101. 
28. Van Rooij D, Blamart D, De Mol L, Mienis F, Pirlet H, et al. (2010) Cold-water coral mounds on the Pen Duick Escarpment, Gulf of Cadiz: the MiCROSYSTEMS approach. Marine Geology.

29. Leon R, Somoza L, Medialdea T, Maestro A, Diaz-del-Rio V, et al. (2006) Classification of sea-floor features associated with methane seeps along the Gulf of Cadiz continental margin. Deep-Sea Research Part Ii-Topical Studies in Oceanography 53: 1464-1481.

30. Mazurenko LL, Soloviev VA, Belenkaya I, Ivanov MK, Pinheiro LM (2002) Mud volcano gas hydrates in the Gulf of Cadiz. Terra Nova 14: 321-329.

31. Niemann H, Duarte J, Hensen C, Omoregie E, Magalhaes VH, et al. (2006) Microbial methane turnover at mud volcanoes of the Gulf of Cadiz. Geochimica Et Cosmochimica Acta 70: 5336-5355.

32. Girguis PR, Cozen AE, DeLong EF (2005) Growth and population dynamics of anaerobic methane-oxidizing archaea and sulfate-reducing bacteria in a continuous-flow bioreactor. Applied and Environmental Microbiology 71: 3725-3733.

33. Rossel PE, Elvert M, Ramette A, Boetius A, Hinrichs KU (2011) Factors controlling the distribution of anaerobic methanotrophic communities in marine environments: Evidence from intact polar membrane lipids. Geochimica Et Cosmochimica Acta 75: 164-184.

34. Blumenberg M, Seifert R, Reitner J, Pape T, Michaelis W (2004) Membrane lipid patterns typify distinct anaerobic methanotrophic consortia. Proceedings of the National Academy of Sciences of the United States of America 101: 1111111116.

35. Grayston SJ, Wang SQ, Campbell CD, Edwards AC (1998) Selective influence of plant species on microbial diversity in the rhizosphere. Soil Biology \& Biochemistry 30: 369-378.
36. Pagaling E, Strathdee F, Spears BM, Cates ME, Allen RJ, et al. (2014) Community history affects the predictability of microbial ecosystem development. ISME J 8: 19-30.

37. Delong EF (1992) Archaea in coastal marine environments. Proceedings of the National Academy of Sciences of the United States of America 89: 5685-5689.

38. Lane DJ (1991) 16S/23S rRNA sequencing. In: Stackebrandt E, Goodfellow M, editors. Nucleic Acid Techniques in Bacterial Systematics: John Wiley \& Sons. pp. $142-175$.

39. Pace NR, Olsen GJ, Woese CR (1986) Ribosomal-RNA Phylogeny and the Primary Lines of Evolutionary Descent. Cell 45: 325-326.

40. Boetius A, Ravenschlag K, Schubert CJ, Rickert D, Widdel F, et al. (2000) A marine microbial consortium apparently mediating anaerobic oxidation of methane. Nature 407: 623-626.

41. Niemann H, Losekann T, de Beer D, Elvert M, Nadalig T, et al. (2006) Novel microbial communities of the Haakon Mosby mud volcano and their role as a methane sink. Nature 443: 854-858.

42. Losekann T, Knittel K, Nadalig T, Fuchs B, Niemann H, et al. (2007) Diversity and abundance of aerobic and anaerobic methane oxidizers at the Haakon Mosby mud volcano, Barents Sea. Applied and Environmental Microbiology 73: 3348-3362.

43. Manz W, Eisenbrecher M, Neu TR, Szewzyk U (1998) Abundance and spatial organization of Gram-negative sulfate-reducing bacteria in activated sludge investigated by in situ probing with specific 16S rRNA targeted oligonucleotides. Fems Microbiology Ecology 25: 43-61. 